\title{
Communication Strategies of DFTW (Domes for The World) in Post-Earthquake Reconstruction and Rehabilitation in Yogyakarta, Indonesia
}

\author{
Nadia Farabi, \\ Department of International Relations, \\ Universitas Diponegoro, \\ Semarang, Indonesia \\ (nadia.farabi@live.undip.ac.id)
}

\author{
Hermini Susiatiningsih, \\ Department of International Relations, \\ Universitas Diponegoro, \\ Semarang, Indonesia \\ (herminisq@yahoo.com)
}

\begin{abstract}
This paper explains how DFTW, a United Statesbased NGO, organized to move Sengir Village residents to Nglepen Baru, after the 2006 Yogyakarta earthquake. Reconstruction and rehabilitation were needed in order to avoid citizens from disaster that devastated their homes and livelihoods. DFTW gave humanitarian aid in the form of dome-shaped houses; semicircle building that proven to be disaster-resilient. However, the aid hardly received warm welcome from the locals, because the house in Java are generally rectangular or square. DFTW success in building dome houses could not be separated from its ability to communicate with the local governments, local organizations, as well as local communities, in order to improve living conditions of the affected communities. The great loss and damage of housing due to the earthquake made all elements agree that reconstruction of houses should prioritize resilience against earthquakes. Thus, in the future, the housing damage could be minimized.
\end{abstract}

Keywords-NGO; communication; disaster response

\section{INTRODUCTION}

The traditional shapes of Javanese houses are basically rectangular or square. But, there is a quite newly-introduced form of house, that is, the Teletubbies house. This type of house is profoundly present in Nglepen Baru, Sleman District, Yogyakarta. The Teletubbies house in Yogyakarta, or dome house because of its appearance, was originally designed by a United States-based non-governmental organization (NGO), DFTW. The Yogyakarta earthquake in 2006 caused the most severe damage to civilian homes, compared to other infrastructures. It gave DFTW the impetus to get involved in humanitarian aid in the form of a number of dome houses because of the disaster-proof construction. Considering the common types of Javanese homes are rectangular or square, the aid hardly received a warm welcome from the locals.

This paper aims to describe the communication conducted by DFTW in order to succeed in building the dome house for Nglepen Baru residents. This paper consists of three parts. First, covers the general illustration about the aid. It is very important to understand it, because it leads to the next part that explains in details about the process of the then-incoming aid. Most of the data provided in this part was taken during the field research in 2015, where researchers had the opportunity to visit Nglepen Baru and interview Sulasmono (the coordinator in Nglepen Baru), as well as Ikaputra (an expert from Universitas Gadjah Mada who happens to be involved during the reconstruction and rehabilitation process). Last part, is the conclusion.

\section{RECONSTRUCTION AND REHABILITATION POST-EARTHQUAKE}

\section{A. Building Disaster-Resilient Community in Nglepen Baru through Dome-Shaped Houses}

DFTW is a non-profit agency based in Texas, United States of America, and was founded by David South in 2006. DFTW's objective is to introduce and promote of what they call as Monolithic Ecoshells. It is a model of building that uses airform technology to construct a one-piece dome, steelreinforced insulated concrete dome for humanitarian purpose. The most appealing element of dome house is it being earthquake-proof, tornado-proof and fire-proof. DFTW has a mission to elevate people's lives around the world by building Monolithic Ecoshells for public and personal uses. Having received many grants and donations from various parties who trust in DFTW's mission, DFTW has built permanent, affordable, clean and safe dome houses for the unfortunates.

DFTW has constructed a number of Monolithic Ecoshells in some countries. Besides aiming to reduce the figure of homeless people who do not own a house, DFTW also has a goal to promote it as a standard disaster-proof building. When the earthquake hit Yogyakarta and its adjacent areas in 2006, DFTW came with the objective to participate in post-disaster reconstruction program in Sengir Village, Sleman District. After the earthquake, many homes in this area were extremely damaged. The devastating earthquake spawned immediate land movement for up to 30 meters. There were no casualties, however, no one was allowed to stay and live in Sengir Village anymore. It also left 66 families homeless because their homes collapsed and most of them were even buried. This became one of the reasons why DFTW wanted to build dome houses for former Sengir Village residents. 
It took six months to construct the houses, involving 370 local workers (DFTW, 2007). Each of dome house in the new area, which is known later as Nglepen Baru, has a living room, two bedrooms and a kitchen. The lavatory was built outside in an area separated from the houses, and could be used collectively. Every lavatory has six bathrooms that could be used by 12 families. In April 2007, 80 units of domes were introduced publicly where 71 of them were to house 71 families and the rest was for lavatory, mosque, kindergarten and health clinic (DFTW, 2007).

\section{B. DFTW Communication during Disaster Response: Prioritizing Community Resilience}

When the earthquake struck, Universitas Gadjah Mada (UGM) established Posko UGM Yogyakarta Peduli Bencana DIY dan Jawa Tengah (Coordinating Center for Natural Disaster in Special Region of Yogyakarta and Central Java). This temporary local-based center consisted of Coordinating Center of Faculty of Technical Sciences, Coordinating Center of Faculty of Geography, Coordinating Center of Faculty of Psychology and Coordinating Center of Faculty of Medicine. All of these coordinating centers worked together in postdisaster programs under the one university, UGM. Therefore, the humanitarian aid for survivors in Yogyakarta Province were not only distributed through government authorities and local NGOs, but also UGM. As a response to the abundance of incoming aid, Coordinating Center of Faculty of Technical Sciences, especially, then formed Jogja-Jateng Archquick Response (JJAR). The center was responsible for geo-hazards mapping and building damage assessment. In practice, this center was not working alone. It was collaborating with various universities, government, international governmental organizations (IGOs) and NGOs.

JJAR was formed so the faculty had its owned clearer reconstruction and rehabilitation mechanisms. Thus, when there were agencies offering assistance for reconstruction and rehabilitation purposes, it had a nickname to represent its vision and mission. Any types of aid related to reconstruction and rehabilitation, when distributed through university, would be handled by JJAR.

Initially, DFTW offered to build dome houses to Coordinating Center for Natural Disaster in Special Region of Yogyakarta and Central Java. The center then decided to proceed it to Coordinating Center of Faculty of Technical Sciences which managed the reconstruction and rehabilitation program. JJAR found the structure of dome house that made it earthquake-proof and the technology employed appealing. But, such characteristic did not automatically make JJAR team accept the offer.

The authority to select and accept the aid in a region is held by local government. Paul Harvey argues that the State's role and obligation in regard to humanitarian aid at least could be seen in four things: State has the authority to declare crisis and invite international-scale humanitarian aid; State provides assistance and protection with its own abilities and resources; State is responsible for supervising and coordinating the incoming foreign aid or assistance; and State bears the responsibility to formulate regulation or legal framework related to the incoming foreign aid (Harvey, 2009: 3). Government has the authority to regulate the aid in order for it to be optimally useful in favour of the survivors, thus keep the new disaster from happening.

When the earthquake hit in 2006, the Indonesian government had not owned a clear regulation to respond to disaster. The immediate response from the government whenever disaster took place had been to issue a decree. Presidential Decree No. 9 Year 2006 on Coordinating Team for Post-Disaster Rehabilitation and Reconstruction in Special Region of Yogyakarta and Central Java became the legal foundation of post-earthquake management.

Such decree was issued by the president in 3 July 2006, in order to advance the post-disaster management program. The decree made it easier for national and local government, civilians and international agencies to coordinate the rehabilitation and reconstruction plan and implement it to the affected areas. All actors involved were called as Coordinating Team, which was divided into two groups: Planning Team and Operating Team. Coordinating Team worked under the president and reported to him. The leader of Operating Team for Special Region of Yogyakarta was the governor of Yogyakarta. Every activity conducted by the leader had to be in accordance with the strategy formulated by Planning Team, which was led by Coordinating Minister of Economic Affairs of Indonesia. Each activity was funded by state budget (APBN), local budget (APBD) and other available resources, for example, foreign aid.

The housing and settlement rehabilitation program became priority. The Coordinating Team's efforts received great supports from various parties including the national government and both local and international donor agencies. With the decree highly implemented, Coordinating Team was able to invite and receive aid. All of the incoming aid, primarily from foreign governments and agencies, had to be under a strict government supervision.

In meeting with Head of District, Ibnu Subiyanto, JJAR discussed the offer from DFTW. The only prerequisite from Government of Sleman District to accept it was the people's approval. Thus, it could be understood that the local government would accept it as long as local people agreed. By local people, the government meant everyone who were about to be relocated, i.e former Sengir Village residents. If and when they agreed to it, the local government were ready to help with regard to permit and other administrative matters, land provision too. Local people had the final say on the offer. DFTW's proposal could not be realized if the locals say no.

After receiving support from local government, DFTW, JJAR and representative of local government visited Sengir Village and met with the chief of village. The chief voluntarily suggested a meeting with residents first. The meeting was attended by DFTW, JJAR, local government representatives, and residents of Sengir Village. DFTW held a presentation in front of them. There were some debates before the people finally agreed to accept the proposal.

With a deep understanding that the form of aid given was considered new, especially to these people, and potentially 
sparked a controversy, DFTW then worked together with Monolithic Inc., including its architects in the negotiation process. The two agencies coalesced into one, under DFTW name. Communication was expected to run smoothly when DFTW could convince them about the quality that dome house had. Almost all the questions asked by JJAR, government and local people were answered well by DFTW.

The DFTW's ability to address almost all the questions could not be separated from how well they mastered the proposal. They fully understood product differentiation that the dome house had thus government, academics and Sengir Village residents welcomed it, eventhough there was a design improvisation took place. Some questions were related to dome house's suitability with tropical climate; the fear of constructing it would cost a great amount of money; the doubt of whether aid receivers would be dependent to DFTW considering its construction required a unique technology; and the question on its shape that was culturally perceveid as inharmonious with the region.

\section{CONCLUSION}

Based on the above explanations, it could be concluded that the success earned by DFTW in giving humanitarian aid in the form of dome houses in Nglepen Baru is because of its ability to communicate well with the decision makers. DFTW's mission is to help States handling vulnerable people affected by disaster. Due to their focus on infrastructure and the willingness to help provide a settlement, DFTW since the beginning worked closely with JJAR, which was given authority by local government to manage post-disaster rehabilitation and reconstruction program. Design-wise, function-wise, and the methods employed during the construction phase were attractive for JJAR. JJAR's interest in original design put forward by DFTW did not automatically make them accept the proposal. The meeting with head of district was done to gain permit and find an area to build dome houses. Lastly, with the help of JJAR, DFTW met with local residents. DFTW has a strong proposal as a basis for communication, which in turn affected the decision makers and local communities to accept the aid. The construction process of dome houses for earthquake survivors proved the participation of all actors, from government, local and international NGOs, donor agencies, academics and civilians.

\section{ACKNOWLEDGMENT}

The researchers of this paper would like to thank Faculty of Social and Political Sciences, Universitas Diponegoro for the financial support, without which the present study could not have been completed. Researchers would also like to gratefully acknowledge Sulasmono from Nglepen Baru, and Ikaputra from Department of Architecture and Planning Universitas Gadjah Mada, for sharing and providing certain data during this study.

\section{REFERENCES}

[1] D, Alexander, "Globalization of Disaster: Trends, Problems, and Dilemmas", Journal of International Affairs, Vol. 59, No. 2, 2006, pp. 123

[2] Ashoka Changemakers, "Domes For The World (DFTW) Constructs Durable Housing and Complete Community Systems For The World's Needy", changemakers $<$ changemakers.com $>$.

[3] D. Benjamin, "Protecting the Protectors: NGO Action and The Responsibility to Protect", International Journal on World Peace, Vol. 26, No. 1, March 2009, pp. 31-50.

[4] AE. Collins, Disaster and Development, Oxon: Routledge, 2009.

[5] DFTW "Final Report: New Nglepen Yogyakarta", Domes for the World $<$ dftw.org $>$.

[6] DFTW “About Us”, Domes For The World $<$ dftw.org>.

[7] Dinas Pekerjaan Umum Provinsi D.I. Yogyakarta, "Program Rehabilitasi Gempa D.I. Yogyakarta \& Jawa Tengah", Dinas <ciptakarya.pu.go.id>

[8] T. Handayani, Model Rekonstruksi Rumah Pasca Gempa Di Yogyakarta Dan Klaten, 2011.

[9] P. Harvey, Towards Good Humanitarian Government: The Role of the Affected State in Disaster Response < odi.org.uk>.

[10] A. Hehir, Humanitarian Intervention: An Introduction. New York: Palgrave Macmillan, 2010.

[11] JL. Holzgrefe and RO. Keohane, Humanitarian Intervention: Ethical, Legal, and Political Dilemmas, Cambridge: Cambridge University Press, 2003.

[12] I. Ikaputra, "People Response to Localize the Imported Culture, Study Case: the Dome House in the Rural Culture Post Javanese Earthquake 2006", iitk<iitk.ac.in/>.

[13] MP. Karns and KA. Mingst, International Organizations: The Politics and Processes of Global Governance, Boulder: Lynne Rienner Publisher, 2004.

[14] M. Pelling, Natural Disasters and Development in a Globalizing World. London: Routledge, 2003

[15] L. Minear and H. Smith, Humanitarian Diplomacy: Practitioners and Their Craft. New York: United Nations University Press, 2007.

[16] Monolithic, Monolithic Dome Today $<$ monolithic.org $>$

[17] T. Saraswati, "Kontroversi Rumah Dome di Nglepen, Prambanan, D.I. Yogyakarta”, Dimensi Teknik Arsitektur, Vol. 35, No. 2, December 2007 pp. 136-142.

[18] MD. Selves, The Politics of Disaster (Principles for Local Emerency Managers and Elected Officials) <training.fema.gov>

[19] T. Vaux, "Humanitarian Trends and Dilemmas", Development in Practice, Vol. 16, No. 3/4, June 2006, pp. 240-254.

[20] M. Walzer, "On Humanitarianism: Is Helping Others Charity, or Duty, or Both?", Foreign Affairs Vol. 90, No. 4, July/August 2011, pp. 69-80. 